\title{
スクラムジェットェンジンの 3 分力測定 \\ 1) マッハ4から 8 飛行条件におけるエンジン抗力*1 \\ Three-Component Force Measurements for Scramjet Engines 1) Engine Drag from Mach 4 to Mach 8 Flight Conditions
}

\author{
樽川雄 $-* 2 \cdot$ 三 谷徹*3.平岩徹 夫*3. 升 谷五 郎*4 \\ Yuichi Tarukawa, Tohru Mitani, Tetsuo Hiraiwa and Goro Masuya
}

Key Words : Scramjet Engine, Internal Drag, External Drag, Pressure Drag, Friction Drag

\begin{abstract}
Aerodynamic performance of scramjet engines was measured by using 0.44-m-long models in a M6.7 wind tunnel. Drags and wall pressure distributions were measured to evaluate the total pressure and friction drag in the engine internal flow. The internal drag of the models with various struts was dicussed. The internal and the external drags, the pressure and the friction drags were estimated. Consistency between the force balance measurements and the pressure measurements was examined. The internal drag obtained from the force balance agreed with that based on the wall pressure measurements.
\end{abstract}

\section{1. は じめに}

航空宇宙技術研究所・角田推進研究所では, ラムジェット エンジン試験設備 (RJTF) を用いたスクラムジェットェン ジン試験が実施されている .このスクラムジェットエンジ ンでは , 着火・保炎性能を改善するために , エンジン内部 にストラットを取り付けている．しかしこれによりエンジ ン内部抗力が増大する. 正味推力は, (燃焼により発生する 推力増分)-(燃料を供給する前のエンジン内部抗力 ) で定 義されるため, 摩擦を含めたエンジン抗力を正確に見積る ことが必要となる。

これまでのスクラムジェットの抗力に関しては , Voland によるエンジン入口と出口間の運動量収支による抗力の見 積り ${ }^{1)}$ や Mitani らによる風洞実験と数値実験の比較 ${ }^{2)} な$ どがある．しかし，これらの方法には，摩擦抗力の見積り に等エントロピ仮定が含まれており, 圧縮比の高いスクラ ムジェツト内部流れに適用するには不適当である.エンジ ン内部の摩擦抗力を正確に見積るためには, エンジン内の 総圧分布が必要で, 谷のためには総圧回復率を見積らなけ ればならない .

この報告では, エンジン全体の総圧回復率からエンジン内 部の総圧分布を求め, 摩擦抗力とエンジン内部抗力を見積る 方法について提案する . マッハ数とレイノルズ数を RJTF に合わせることにより，燃焼が起こっていない気流状態の 3

\footnotetext{
*1 C) 2003 日本航空宇宙学会

平成 14 年 3 月 12 日, 2001 年度日本航空宇宙学会北部支部講演 会にて発表. 平成 14 年 8 月 19 日原稿受理

*2 (株) ケーヒン

*3 航空宇宙技術研究所角田宇宙推進技術研究所

$* 4$ 東北大学大学院工学研究科
}

分力 (抗力 , 揚力 , ピッチングモーメント) の測定は, RJTF の $1 / 5$ 縮尺の小型風洞3) でも可能となる .ここでは , 小型 風洞と $1 / 5$ 縮尺エンジン模型, ならびに各種ストラットを 用いて，M4，6，8 各飛行条件で壁圧分布と抗力を同時測 定した . そして炎れ光れの測定值を用いて, エンジン全体 の総圧回復率とエンジン内部抗力を見積った .これら $2 つ$ の独立な見積り法で内部流を比較することで, 相互の精度 の検証を行った . また第 2 報では，同じ手法により揚力と ピッチングモーメントの見積りと，外部流に対する補正法 および境界層吸い込みの影響についてまとめた ${ }^{4)}$. 主な記 号は文末に示す.

\section{2. 実験装置および方法}

$2.11 / 5$ 縮尺壁圧: 抗力模型 第 1 図に実験に用いた E2 エンジン ${ }^{5)}$ の $1 / 5$ 縮尺模型を示す . このエンジン模型は , 2 枚の側板と下方のカウル, 上方の天板からなる矩形の側板圧 縮型エンジンである .エンジン内部流路はインレット入口と ノズル出口が同寸法になっており，模型全長は $L=440 \mathrm{~mm}$ ， 流路高さは $H=50 \mathrm{~mm}$, 幅は $W=40 \mathrm{~mm}$ である . 模型 全長を代表長さとした $R e$ 数は，M 8 で $1.5 \times 10^{7}, \mathrm{M} 6$ で $1.3 \times 10^{7}$ で，M4では $2.8 \times 10^{7}$ である．

インレット側板には 45 度の後退角がついており, 前縁部 の半頂角 6 度のくさびにより空気を圧縮する . インレット と燃焼器の間には, 燃焼時に燃焼による圧力上昇の上流へ の遡りを抑制するために分離部を設けた . 燃焼器入口には 高さ $0.8 \mathrm{~mm}$ の後ろ向きステップがある . 燃焼器からの気 流は, 拡大角 1.9 度の拡大部と 6.9 度のノズルで膨張し推 力を発生する.エンジン内壁には, 約 130 点の圧力測定孔 を設け, 3 連の機械式スキャナで壁圧を測定した .また，壁 


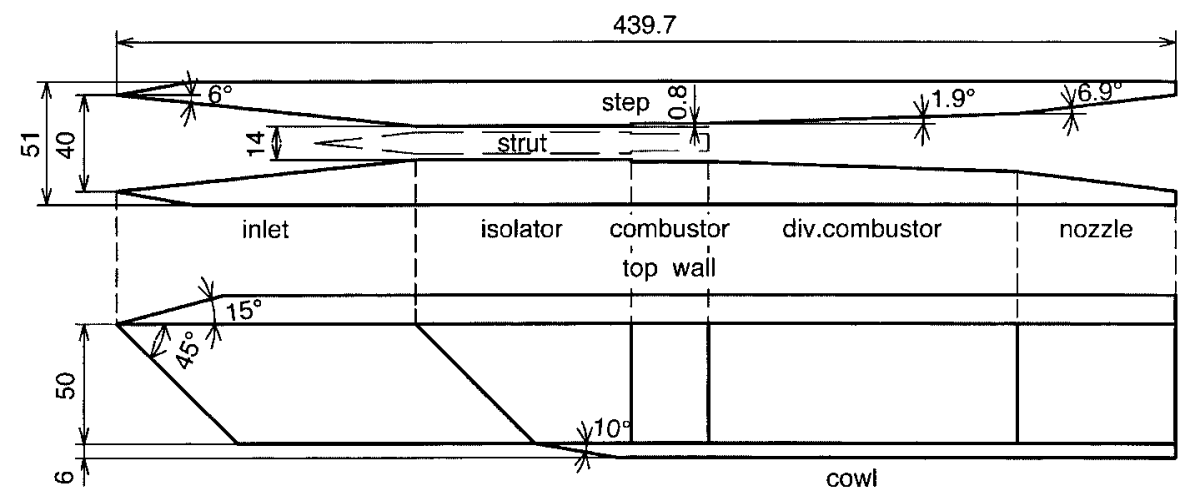

第1図ＲJTF 補完用に，マッハ数とレイノルズ数を合わせた $1 / 5$ 縮尺エンジン模型 (E2 エンジン)

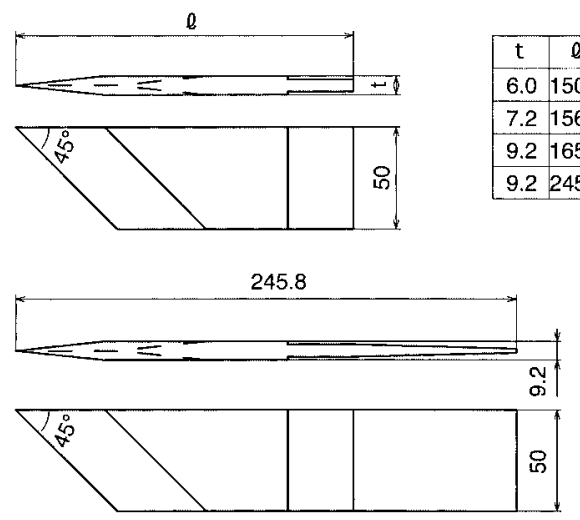

(a) short-strut and long-strut

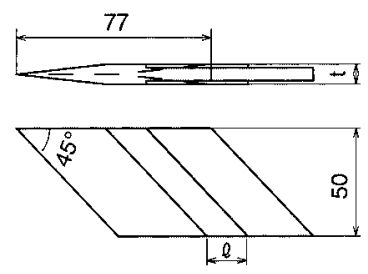

(b) swept-back-strut

第 2 図 インレットスロート部に設置するストラット

圧測定用圧力導管は，全て模型側壁に内蔵した . 兴れによ り，壁圧と抗力の同時測定が可能となった .

第 2 図には実験に用いた各種のストラットを示す . スト ラットは, 弚の肩口がエンジンの分離部入口と一致するよ うに取り付けた . ストラットの種類には大きく分けて , (a) のインレット部のみに後退角のついたストラットと, (b)の 全体に後退角のついたストラットがある . (a) のストラット にはさらに, 短と長の 2 種類のストラットがある . 短スト ラットのうち $6 \mathrm{~mm}$ 厚ストラットは, RJTF では M6 試験 に使用された $30 \mathrm{~mm}$ 厚ストラットに相当する . しかし M8 では保炎性能が不十分なため, $9.2 \mathrm{~mm}$ 厚ストラットに相当 する $46 \mathrm{~mm}$ 厚とより厚いストラットが用いられた . $9.2 \mathrm{~mm}$ 厚短ストラットは $9.2 \mathrm{~mm}$ 厚長ストラットの下流側を切り 落とした形態になっており，RJTF の燃焼試験で相当する ストラットを用いて，抗力および燃焼性能を比較した5) . ま た (b)のストラットは, エンジン全体に後退角のついた E1
エンジン用に製作したものである .

ここでは,これらのストラットを第 1 图のエンジン模型に 装着し，インレットの収縮比 (エンジン入口断面積/スロー 卜断面積） $\varepsilon$ を変化させた．乥して，ストラット厚さ，お よびストラット形状の違いによる内部抗力の変化を調べた .

2.2 実験方法 実験は最も不始動に陥りやすい M8 飛 行条件から始め, M8 試験で確立した実験手法で, M6，M4 条件の実験を行った . 風洞流体に常温空気を用いると空気 の液化が起きるため，M6，M8 実験では，蓄熱体により総 温を $600 \mathrm{~K}$ 以上に加熱した高温空気を用いた . 流れ方向 $(x$ 方向)の模型天板前縁位置は, ノズルの熱膨張によりノズ ルとエンジン模型が接触するのを防ぐため, ノズル端面か ら $5 \mathrm{~mm}$ の位置とした .

また M8 実験では, ノズル境界層をエンジンか吸い込む と内部流が不始動になったため, トラバースにより模型の 取り付け位置を $10 \mathrm{~mm}$ 気流側に移動させて $(y=10 \mathrm{~mm})$, 抗力を測定した .この時エンジンに入る境界層の厚さは, 境 界層の一部を取り除いたため，排除厚さで $1.6 \mathrm{~mm}$, 運動 量厚さは $0.086 \mathrm{~mm}$ となっている. M6 実験では, 内部流 不始動を避けるため, $y=5 \mathrm{~mm}$ の位置で抗力を測定した . この時エンジンに入る境界層の排除厚さは $4.2 \mathrm{~mm}$, 運動 量厚さは $0.3 \mathrm{~mm}$ である. $\mathrm{M} 4$ 実験では, $y=0 \mathrm{~mm}$ の位置 でも内部流は始動した .

本実験では，まず天板のみの形態での抗力を測定し，弚の 值をエンジン形態での抗力から差し引いて, エンジン抗力と した .エンジン抗力の測定には, FMS (Force Measuring System) を用いた。実験で得られた模型抗力は, エンジン 入口動圧 $q_{1}$ とエンジン入口断面積 $A_{1}(=H \times W)$ を用いて 無次元化し, 抗力係数 $C d\left(=D / q_{1} / A_{1}\right)$ で整理した . また 壁压 $P_{\mathrm{w}}$ については, 圧力係数 $C p\left(=P_{\mathrm{w}} / q_{1}\right)$ で整理した .

\section{3. 実験結果と考察}

\section{1 抗力測定による方法}

3.1.1 エンジン内部抗力 ここでは 2 つの方法で，エン ジン内部抗力とエンジン全体の総圧回復率を見積った . 第 一の抗力測定による方法は, FMS で測定した抗力を用いて エンジン入口と出口間の総圧回復率 $\eta_{\mathrm{p} 5 \mathrm{I}}$ を求める方法であ る.この方法では, まずFMS で測定したエンジン抗力か 
第 1 表 模型形態と乥れぞれの抗力係数, 総圧回復率, および総圧低下特性距離 (M8 条件)

\begin{tabular}{|c|c|c|c|c|c|c|c|c|c|c|c|}
\hline$\overline{\mathrm{A}}$ & $\bar{B}$ & $\bar{C}$ & $\overline{\mathrm{D}}$ & $\bar{E}$ & $\overline{\mathrm{F}}$ & $\overline{\mathrm{G}}$ & $\overline{\mathrm{H}}$ & $\bar{I}$ & $\overline{\mathrm{J}}$ & $\overline{\mathrm{K}}$ & $\overline{\mathrm{L}}$ \\
\hline \multicolumn{3}{|c|}{ Condition } & \multicolumn{4}{|c|}{ Method 1} & \multicolumn{5}{|c|}{ Method 2} \\
\hline Model & Strut & $\varepsilon$ & $C_{\mathrm{FMS}}$ & $C_{\text {tot }}$ & $C_{\text {int I }}$ & $\eta_{\mathrm{p} 5 \mathrm{I}}$ & $\eta_{\mathrm{p} 5 \mathrm{II}}$ & $X_{\mathrm{p}}^{*}(\mathrm{~mm})$ & $C d_{\mathrm{p}}$ & $C d_{\mathrm{f}}$ & $C_{\text {int II }}$ \\
\hline $\mathrm{A}$ & $\mathrm{w} / \mathrm{o}$ & 2.86 & 0.253 & 0.167 & 0.075 & 0.342 & 0.500 & 599 & 0.001 & 0.058 & 0.060 \\
\hline B & $6.0 \times 151$ & 5.00 & 0.318 & 0.232 & 0.133 & 0.162 & 0.164 & 229 & 0.017 & 0.116 & 0.132 \\
\hline $\mathrm{C}$ & $7.2 \times 156$ & 5.88 & 0.339 & 0.253 & 0.156 & 0.117 & 0.107 & 186 & 0.036 & 0.126 & 0.162 \\
\hline $\mathrm{D}$ & $9.2 \times 166$ & 8.33 & 0.454 & 0.368 & 0.273 & 0.035 & 0.037 & 126 & 0.112 & 0.155 & 0.268 \\
\hline $\mathrm{E}$ & $9.2 \times 246$ & 8.33 & 0.408 & 0.322 & 0.227 & 0.062 & 0.052 & 140 & 0.072 & 0.172 & 0.244 \\
\hline $\mathrm{F}$ & $6.0 \times 77$ & 5.00 & 0.389 & 0.232 & 0.133 & 0.141 & 0.107 & 227 & 0.028 & 0.097 & 0.124 \\
\hline G & $9.2 \times 77$ & 8.33 & 0.318 & 0.303 & 0.208 & 0.059 & 0.048 & 137 & 0.128 & 0.100 & 0.228 \\
\hline
\end{tabular}

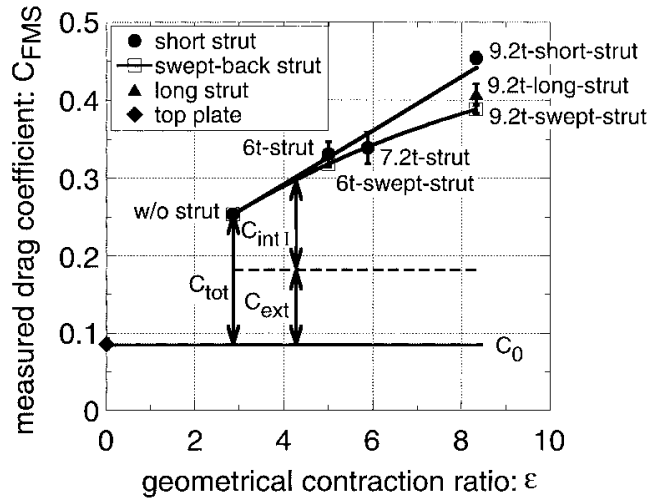

第 3 図 M8 飛行条件における抗力係数と収縮比の関係

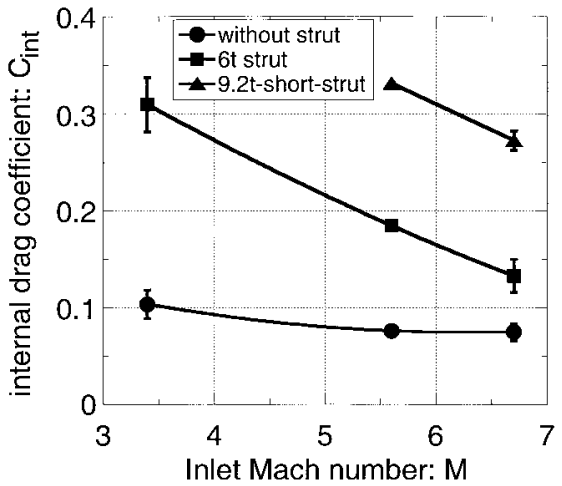

第 4 図内部抗力におよぼすストラットとマッハ数の影響
ら天板のみの形態での抗力を差し引いて , 天板からの増分 を調べる . 炎のエンジン全抗力から外部抗力を差し引いて 内部抗力を求める .このようにして得られたエンジン内部 抗力を用いて， $\eta_{\mathrm{p} 5 \mathrm{I}}$ を求める.

第 1 表に M8 実験時の抗力についてまとめた . A 列が模 型名, B 列が使用したストラット，C列が乥れ光れの形態に おける収縮比 $\varepsilon$ を示している.FMS で測定した抗力 $C_{\mathrm{FMS}}$ を第 1 表の D 列に示す . $\mathrm{E}$ 列は D 列の測定值から天板の みでの抗力 $C_{0}(=0.086)$ を差し引いた抗力係数で, エンジ ン内外部で発生する全抗力 $C_{\text {tot }}$ である . これから外部抗力 $C_{\text {ext }}(=0.096)$ を差し引いた残りがエンジン内部抗力 $C_{\text {int I }}$ で，弚の値を第 1 表の F 列に示した . また，これらの結果 を第 3 図に整理した。

第 3 図の横軸には $\varepsilon$, 縦軸には $C_{\mathrm{FMS}}$ をとった . エラー バ一は標準偏差 $\sigma$ を用いて , $\pm \sigma て ゙$ 表した . 図中の○は短 ストラット, $\boldsymbol{\Delta}$ は長ストラット, $\square$ は後退角付きストラッ 卜装着時の $C_{\mathrm{FMS}}$ である. $C_{0}(=0.086 \pm 0.0067)$ の水平 線は, 天板のみでの抗力を示している. 炎して， $C_{0}$ から $C_{\mathrm{FMS}}$ までの矢印が, $C_{\mathrm{tot}}\left(=C_{\mathrm{FMS}}-C_{0}\right)$ となっている.

また , 図中の $C_{0}$ を示す水平線と破線間は $C_{\mathrm{ext}}(=0.096 \pm$ $0.0064)$ である. 产の值は, 側板およびカウルの外側くさび 面とエンジン後端のベース面に働く圧力抗力 , ならびに , 外 壁の摩擦抗力からなる. 弚のうち側板外側くさび面とベース 面の圧力抗力は，关れ光れ抗力係数で $0.045,-0.015$ となっ た . カウルくさび面での圧力抗力は, 偏角を持つスピル流 が, カウル前縁の 10 度のくさびに沿うために生じる波の計 算から求めた . この值は模型形態により異なるが, $0.033 〜$
0.040 と全体抗力に対して小さかった . 谷こで図中では平 均值 0.037 で示し, 内部抗力の見積りは, 模型形態ごとに 行った . 外壁の摩擦抗力は 0.029 と見積った .つまり外部 抗力のうち $69 \%$ が圧力抗力, 残りの $31 \%$ が摩擦抗力であ る.このようにして外部抗力が求まれば, FMS 測定值から 内部抗力を分離できる . 図中では破線から $C_{\mathrm{FMS}}$ までの矢 印が, $C_{\text {int I }}\left(=C_{\text {tot }}-C_{\text {ext }}\right)$ である

以上より, 全抗力に占める内部抗力は, 収縮比の増加に 伴い, 模型 A での $45 \%$ から模型 D では $74 \%$ に増加した . 同じ $\varepsilon$ の場合， $6 \mathrm{~mm}$ 厚ストラット付きではストラットに 後退角がある場合とない場合で, 内部抗力は同程度になっ た .しかし $9.2 \mathrm{~mm}$ 厚ストラット付きでは, 短ストラット から長ストラットに変えると, 内部抗力は $17 \%$, 後退角付 きストラットに変えると， $24 \%$ 低下した .このように，後 退角による抗力の低下は収縮比が大きくなるほど顕著に現 れた .

第 4 図に内部抗力と $\mathrm{M}$ 数の関係を示す . 図よりストラッ 卜なし（O），6 mm 厚ストラット付き (ם) ，9.2 $\mathrm{mm}$ 厚短 ストラット付き $(\boldsymbol{\Delta})$ の 3 形態とも，M 数が大きくなるに 従い内部抗力が低下している .これは $\mathrm{M}$ 数の増加に伴い， 側板前縁とストラット前縁で生じる衝撃波の角度が小さく なり，インレット内での衝撃波の反射回数が減るためであ る.結果としてインレット抗力は低 $M$ 数ほど増大する . 収 縮比の大きな模型ほどこの傾向が強い .

ストラットなしの場合，M4でも側板前縁で生じた衝撃 波の反射回数が少なく, $\mathrm{M}$ 数か変化しても, 内部抗力はあ まり変化しない. $6 \mathrm{~mm}$ 厚ストラットを付けると, M8 から 
M6 では抗力係数は 2 倍に，M4 では 3 倍に増加した .こ の M4 での急激な内部抗力増加は, ストラット両脇の最狭 部で流れが摩擦閉塞を起こしたためである.従って $9.2 \mathrm{~mm}$ 厚ストラットに比べて抗力が小さい $6 \mathrm{~mm}$ 厚ストラットは， $\mathrm{M} 6$ 以上の高 $\mathrm{M}$ 数域で有用である .

3.1.2 インレット流れ解析 入口と出口の面積が等しい 供試エンジンの場合, 内部流が等エントロピ流れで, かつ スピルがなければ, 内部抗力は発生しない . 即ちエンジン 内部抗力は, 内部流の非可逆的な損失つまり衝撃波, スピ ルおよび摩擦によるものである.

Mitani らは, エンジン内部形状を与えた時の内部抗力係 数とエンジン前後の総圧回復率を, 空気捕獲率, インレット の付加抗力, 総温保存率, およびエンジンの吸い込む境界 層厚さの関数として定式化した ${ }^{6)}$. 乥れを用いると, 空気捕 獲率, 付加抗力, 総温保存率, 境界層厚さを独立なパラメー タとして，光れ光れがダクト抗力 $C_{\mathrm{duct}}=\left(C_{\mathrm{int}}-C_{\mathrm{add}}\right)$ に およぼす影響度を定量化できる．弚こで, M8 条件の模型 $\mathrm{E}$ で, 測定值に対する感度解析を行った。光の結果, 境界層 厚さおよび付加抗力の影響は無視できること，また，空気 捕獲率および総温保存率の影響か強いことが分かった . 特 に総温保存率は，総圧回復率の見積りに強く影響するため， 加熱空気を用いる風洞実験では, 総温の測定が重要である . 例えば，M8 条件における模型 $\mathrm{E} の \eta_{\mathrm{T} 0}$ は 0.92 であった . ここで抗力測定より得られたエンジン内部抗力 $C_{\mathrm{int} \text { I }}$ か ら，エンジン全体の総圧回復率 $\eta_{\mathrm{p} 5}$ を見積る . 兴のために は, まず後退角を持つインレット内の衝撃波計算を行い, 光 の空気捕獲率 $\eta_{\mathrm{c}}$ と付加抗力 $C_{\text {add }}$ を見積る必要がある.

後退角付き側板圧縮型インレット内の流れを，無限に長 い後退角付きくさび間の非粘性流れと考える . 気流の速度 ベクトルを後退角に対して垂直な成分と平行な成分に分解 し，垂直な成分について衝撃波関係を適用すれば，インレッ 卜内部流れを計算できる ${ }^{4)}$. スピルはカウル水平面に相当 する断面の, カウル前縁より上流の開放部 (第 1 図を参照) を横切って流れる流量として, 求めることができる.ここ では，このような後退角付きインレットの流机解析を行い， 衝撃波の位置と乥こでの流れ角から, エンジン内部流れと スピル流とを分離する流線を求める. 分離流線が求まれば， 弚れからスピル面積が求まり, 弚れと $A_{1}$ との比から $\eta_{\mathrm{c}}$ を 計算できる。

最初に兴のインレット流れ解析の精度を確認するために， $\mathrm{M} 6$ 飛行条件の $9.2 \mathrm{~mm}$ 厚短ストラットについての解析結果

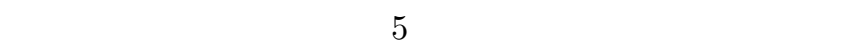
れ側板上とストラット上における壁圧の実験值である . ま た, 実線が側板上の解析値, 破線がストラット上の解析值 を示している。

流れ解析では側板前縁で生じた衝撃波とストラット前縁 で生じた衝撃波か洨差し，关の交差した波の一方が $x / H=$ 1.6 でストラットに入射する. 兴の結果，入射後の圧力は $P_{\mathrm{w}} / q_{1}=0.4$ まで昇圧する.この波はストラットで反射後， 以前交差したもう一方の波と合体し， $x / H=2.15$ で側板 に入射する. 兴の結果，乥こでの圧力は $P_{\mathrm{w}} / q_{1}=1.0$ まで

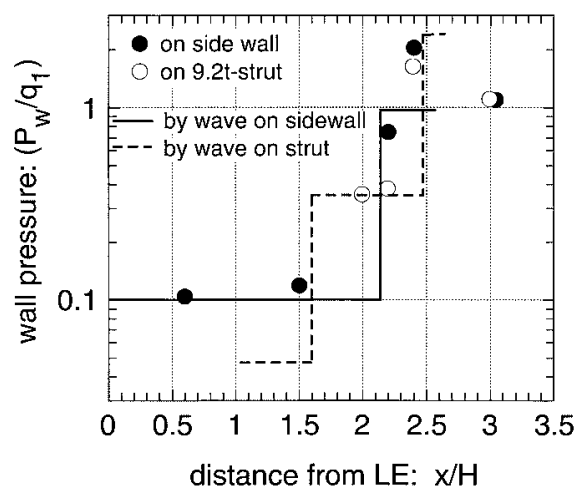

第 5 図 M6 飛行条件における非粘性計算と実験値の比較

上昇する.さらに，光の波は側板で反射して $x / H=2.45$ で再びストラットに入射し，圧力は $P_{\mathrm{w}} / q_{1}=2.5$ まで上昇 する.この後，ストラットからの反射波は分離部内に入る . 粘性の効果により，実験值の方が上流で圧力が上昇するが， 図に示す通り，側板，ストラットともに実験值と解析值は よく一致した . 従って , このインレット計算の精度は十分 高い.

インレット内部流れが決まると, 分離流管に働く静圧と 产の受圧面積を積算することにより，スピル流が作る圧力 による付加抗力を計算できる . また，スピル流と側板およ びストラット面との間の摩擦による付加抗力は, 各濡れ面 での動圧と面積，および表面摩擦係数から求まる. 光して, 付加抗力の圧力分と摩擦分を足し合わせれば $C_{\text {add }}$ が決ま る. 以上の方法により得られた $\mathrm{M} 8$ 飛行条件での $C_{\text {add }}$ は，

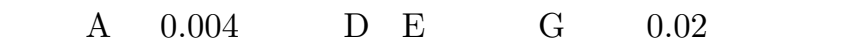
力中 $4 \sim 6 \%$ で内部抗力や外部抗力に比べて小さかった . こ のように側板圧縮型インレットでは, マッハ数が高くなる とスピルが咸少するため, $C_{\text {add }}$ の全抗力に占める割合は小 さくなる．

このように $C_{\mathrm{add}}$ と $\eta_{\mathrm{c}}$ が決まれば，エンジン入口と出口 間の総圧回復率 $\eta_{\mathrm{p} 5 \mathrm{I}}$ を求めることができる.M8 飛行条件 での各模型形態における $\eta_{\mathrm{p} 5 \mathrm{I}}$ を第 1 表 $\mathrm{G}$ 列に示す . ス卜 ラットを装着すると総圧回復率は急激に低下する .これは ストラットの装着により，衝撃波による総圧損失と摩擦に よる総圧損失か増大するためである . 厚いストラットを装 着した模型，つまり収縮比の高い模型ほど衝撃波による損 失は大きくなる．またストラットの濡れ面積が大きい模型 ほど，摩擦による損失も大きくなる．結果として， $\eta_{\mathrm{p} 5 \mathrm{I}}$ は 模型 A での $34 \%$ から模型 D では $4 \%$ まで低下した .

\section{2 壁圧測定による方法}

3.2.1 圧力抗力 ここでは, 壁圧測定值を用いて, 内部 抗力を見積る第二の方法について説明する . 測定した M8 飛行条件における側板上の壁圧を主流の動圧で無次元化し， 等高線分布にして第 6 図に示した . 図中の黑点は測定孔位 置を, また○印で最高圧, $\times$ 印で最低圧位置を示し, 光 れらの值を各図の下に記した . (a) が模型 D を , (b) が模 型 $\mathrm{E}$ を, (c) が模型 $\mathrm{G}$ を示す.

第 6 図 (a) 模型 D では，圧力測定孔第 3 列圧が上昇し， 
(a) model D (9.2t-short-strut)

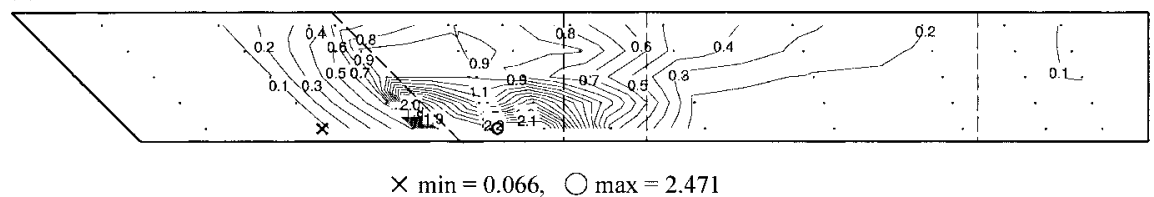

(b) model E (9.2t-long-strut)

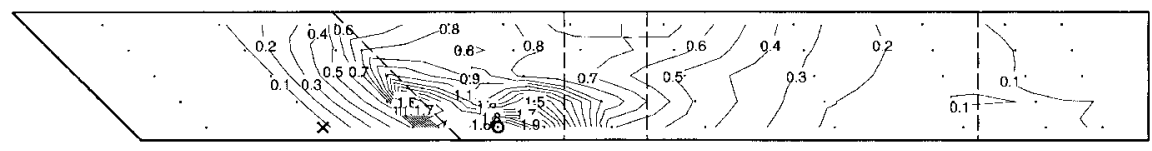

$\times \min =0.061, \bigcirc \max =2.494$

(c) model G (9.2t-swept-strut)

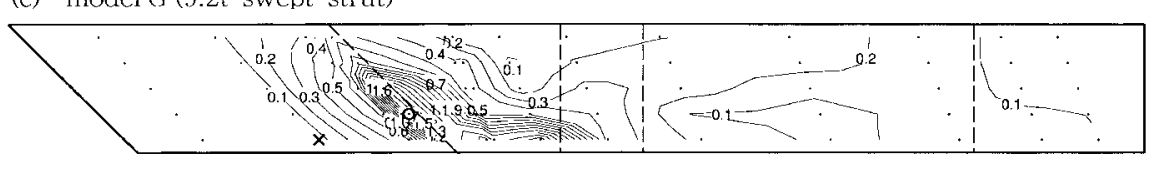

$\times \min =0.056, \bigcirc \max =1.710$

第6 図 ストラット形状が側壁圧分布におよぼす影響 ( $\mathrm{M} 8$ 飛行条件, $C p=P_{\mathrm{w}} / q_{1}$ )

乥れを内挿して描いた等高線は，第 2 列と第 3 列間になだ らかな分布となった . インレット部での衝撃波入射による 圧力上昇は, 天板とカウル側で小さく，高圧域が島状になっ ている. 天板側の低圧の原因は, 弚こで発達した厚い境界 層と天板前縁からの膨張波にある . またカウル側で圧力が 低下するのは，側板下側からスピルする流れに伴う膨張波 が原因である .

スピル流とカウル前縁が作る衝撃波の影響により，燃焼 器平行部圧力は最大になり, 光の值は $P_{\mathrm{w}} / q_{1}=2.47$ となっ た . 燃焼器以降，壁圧は流路の拡大に伴い，ノズルに向かっ て減少する.第 6 図 (a) の模型 D の $9.2 \mathrm{~mm}$ 厚短ストラッ 卜後端は, 切り落としとなっているため, 乥こからの強い 膨張波が燃焼器拡大部に入射している.

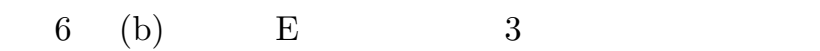
圧力が上昇している．これは側板前縁で生じた衝撃波とス トラット前縁で生じた衝撃波の干渉により生じる強い衝撃 波の影響である . 分離部付近には, インレットと平行部と が作る肩部で発生した膨脹波により，低圧部ができている のが分かる.

カウルから天板へ向かう衝撃波により，分離部で最大圧 力 $P_{\mathrm{w}} / q_{1}=2.49$ を示した．乥の衝撃波は燃焼器拡大部で 天板に入射し，反射された波は再びカウル側へと向かう.模 型 $\mathrm{E}$ に取り付けている $9.2 \mathrm{~mm}$ 厚長ストラットの後端は流 線形としているため, 乥こからの膨脹波は弱い，弚の結果， 燃焼拡大部の側壁圧はなだらかに低下していく.

第 6 図 (c) の模型 $\mathrm{G}$ の場合も，インレット部分は収縮比 が等しいため, 模型 $\mathrm{D}$ や $\mathrm{E}$ と同じような圧力分布となる . しかし分離部に入るとすぐに, 模型 $\mathrm{D}$ および $\mathrm{E}$ よりも圧力 が低下する .これはストラットのステップで生じる膨張波 の影響である .さらに光の下流では, ストラットの後端か ら生じる強い膨張波により，圧力が一段と低下している樣 子が分かる.このように，ストラットからの膨張波により 分離部での圧力が低下するため, 模型 $\mathrm{G}$ での最大圧力は，

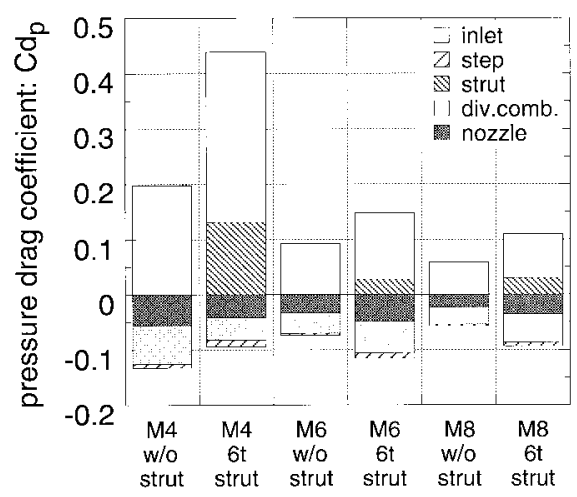

第7図 M4，6，8 各飛行条件における圧力抗力発生分布

インレット出口付近で $P_{\mathrm{w}} / q_{1}=1.71$ となった .

第 6 図に示したような壁圧分布を $13 \times 5$ の各微小面積要 素について圧力積分すれば，側板に働く内部圧力抗力を見 積ることができる . 天板 , カウル , ストラットについても 同樣である . 兴のようにして得られた各部の圧力抗力の総 和が, エンジン内部に働く圧力抗力であり，M8 での圧力 積分值 $C d_{\mathrm{p}}$ を第 1 表 $\mathrm{J}$ 列に示した。

次に第 1 表 $\mathrm{J}$ 列の $C d_{\mathrm{p}}$ の值について, 兴の内訳をまとめ る.模型形態による圧力抗力の発生分布の違いについては， $\mathrm{M} 8$ 飛行条件で調べた ${ }^{7)}$. 第 7 图を用いて M 数による圧力 抗力の発生分布の違いについて議論する.第 7 図にM4,6， 8 の各飛行条件におけるストラットなしと $6 \mathrm{~mm}$ 厚ストラッ 卜付きの圧力抗力発生分布を示した . 図では縦軸の正の値 が抗力を，負の值が推力を表している．つまりインレット， ストラットでは抗力を発生し, ステップ, 燃焼器拡大部, ノ ズルでは推力を発生する . 抗力分と推力分の差し引きによ り，エンジン内部の圧力抗力が決まる .

M6や M8 において，インレットとストラットで生じる 圧力抗力の和は, ステップ, 燃焼器拡大部, ノズルで生じる 各部の圧力推力の和よりも大きい . しかし光の差はわずか 
スクラムジェットエンジンの 3 分力測定 $\quad 1)$ マッハ 4 から 8 飛行条件におけるエンジン抗力 (樽川・三谷・平岩・升谷) 59

である.一方 M4 では, 圧力推力分に比べて, 圧力抗力分 がかり大きい. 光のため, エンジン内部流路に働く圧力 抗力は，M6，M8 に比べて大きくなる.これは前述したよ うに低 $\mathrm{M}$ 数ほど衝撃波角が大きく，インレット内での衝撃 波の反射回数が多くなり，圧力が高くなるためである．こ の傾向は，ストラットを装着することでより顕著になる．

3.2.2 摩擦抗力 エンジン内部の摩擦抗力を見積るため には，内部流の総圧分布を知る必要がある． $x$ を流れ方向， $y$ を高さ方向， $z$ をスパン方向とすると，エンジン内の総 圧回復率は, $\eta_{\mathrm{p}}(x, y, z)$ で与えられる.しかし以下では一 次元的に取り扱うため, $y-z$ 平面で平均化して, 流れ方向 のみ関数と仮定する .

流れの熱損失が小さければ，総圧は流れ方向に単調減少 するので,ここでは光の総圧分布を, 総圧特性長さ $x_{\mathrm{p}}^{*}$ を 用いて指数関数で近似した ${ }^{6)}$. この場合， $x_{\mathrm{p}}^{*}$ は第二の方法 (壁圧測定) による総圧回復率 $\eta_{\mathrm{p} 5 \mathrm{II}}$ とエンジン全長から計 算することができる.$x_{\mathrm{p}}^{*}$ が決まれば，任意の $x$ 位置での総 圧回復率と総圧が決まる.エンジン内部での総圧が決まれ ば, 総圧/静圧比から M 数が決まる.このようにして求め た，M4，6，8 飛行条件における，ストラットなし形態の 側板中心線上の $\mathrm{M}$ 数分布を第 8 図に示す .

横軸は前縁からの距離 $x$ をエンジン高さ $H$ で無次元化 して示した . 図より衝撃波と摩擦により, インレット出口 では M4 飛行条件 (O) でM2.1，M6 飛行条件 (口) では M3.8, M8 飛行条件 $(\triangle)$ では M4.6 まで M 数が低下し た . 㚇の下流の燃焼器拡大部およびノズルでは, 流路の拡 大に従い M 数が上昇し, エンジン出口では M4 飛行条件 でM2.9，M6 飛行条件では M4.1，M8 飛行条件では M5.5 まで M 数が回復した . なお, M4 で $6 \mathrm{~mm}$ 厚のストラット を装着した場合のインレット出口での M 数は M1.5 , M8 で $9.2 \mathrm{~mm}$ 厚のストラットを装着した場合では，M2.9 で あった 。

第 8 図のように M 数が決まれば, 局所の総温から静温が 求まる. 局所の静温が求まれば, 兴の值と局所 $\mathrm{M}$ 数から光 の場の流速, 密度, 粘性係数が求まる. 产れらから $R e$ 数 が求まり，次の式を用いて壁面摩擦係数 $c_{\mathrm{f}}$ を計算できる ${ }^{8)}$.

$$
c_{\mathrm{f}}=\frac{a \cdot\left(1+\frac{\gamma-1}{2} \cdot M^{2}\right)^{-0.467}}{(\log \operatorname{Re} x)^{2.58}}
$$

$a$ の值は，局所值 $c_{\mathrm{f}}$ にするためここでは 0.38 とした .こ れは本実験に用いた $1 / 5$ 縮尺風洞の境界層検定実験で測定 した運動量厚さから見積った7)

このようにして壁面摩擦係数分布が得られれば, この分 布と動圧から壁面せん断応力が求まる. 弚して壁面せん断 応力について面積積分を行えば，壁面に働く摩擦抗力を計 算できる .この摩擦抗力に上述の圧力抗力を加えれば，壁 圧測定のみからエンジン内部抗力を見積ることができる . この内部抗力と 1 次元解析から新しい総圧回復率 $\eta_{\mathrm{p} 5}$ II が 得られる.この $\eta_{\mathrm{p} 5 \mathrm{II}}$ を用いて繰り返し計算をすれば，内 部摩擦抗力について収束值 $C_{\mathrm{int} I \mathrm{II}}\left(=C d_{\mathrm{p}}+C d_{\mathrm{f}}\right)$ が求ま

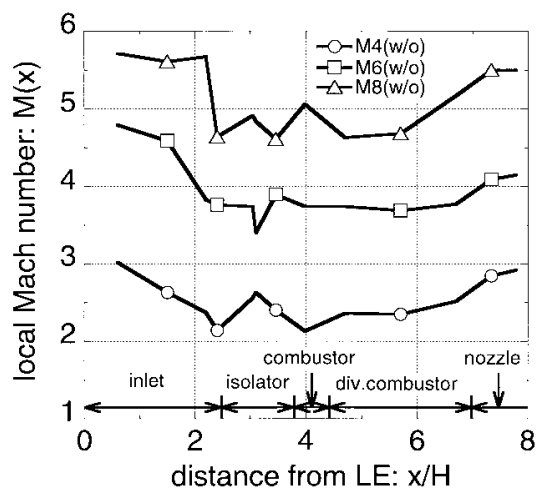

第8图 M4，6，8 飛行条件におけるストラットなしエンジンのマッ 八数分布 (測定位置は側板中央 : $y=H / 2$ )

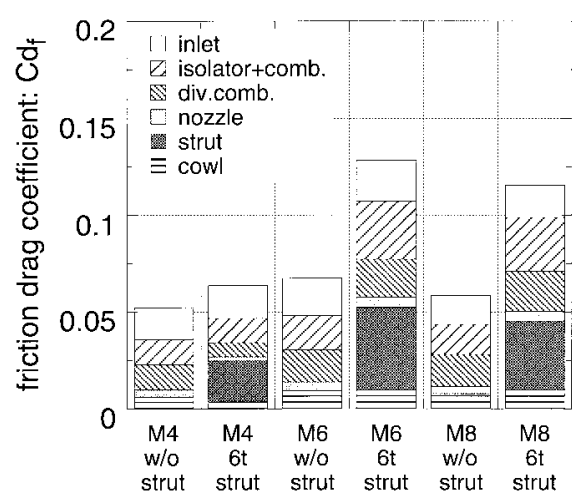

第9図 M4,6,8 各飛行条件における摩擦抗力発生分布

る. 弚の結果，第二の方法による最終的な $\eta_{\mathrm{p} 5 \mathrm{II}}$ が求まる. このようにして得られた $\eta_{\mathrm{p} 5 \mathrm{II}}$ を第 1 表 $\mathrm{H}$ 列に示した . ま た，弚の時の $x_{\mathrm{p}}^{*}$ を第 1 表 I 列に，Cd $d$ を第 1 表 $\mathrm{K}$ 列に， $C_{\text {int II }}\left(=C d_{\mathrm{p}}+C d_{\mathrm{f}}\right)$ を第 1 表 L 列に，弚れ光れ示した .

これらの結果から，第 9 図にM4，6，8 飛行条件におけ るストラットなしと $6 \mathrm{~mm}$ 厚ストラット付き形態の内部摩 擦抗力の発生分布を示した . 模型形態による摩擦抗力の発 生分布の違いについては, 文献 7) を参照されたい.

第 9 図中では側板の摩擦抗力をインレット，スロート部 (分離部 + 燃焼器平行部), 燃焼器拡大部, ノズルに分けて 表示した . 従って,これら各部での総和が側板に働く摩擦 抗力である. 弚の值は，ストラットを装着することにより， 収縮比の増加とともに増加した . これは壁面摩擦係数のマッ 八数依存性により，収縮比が大きい模型ほどスロート部で の壁面摩擦係数が大きくなり, 产の結果摩擦抗力が大きく なるためである7 ${ }^{7} . \mathrm{M} 4$ 飛行条件における $6 \mathrm{t}$ ストラット付 きでは, M6，M8 での $6 \mathrm{~mm}$ 厚ストラット付きよりも壁摩 擦係数が大きいにもかかわらず, 摩擦抗力係数は小さくなっ た .これは M6，M8 に比べて動圧が大きいためである .

3.2.3 圧力抗力と摩擦抗力の内訳 第 10 図に M4, 6,8 各飛行条件におけるストラットなしと $6 \mathrm{~mm}$ 厚ストラット 付きェンジン形態での，内部流における第二の方法で求め た内部抗力 $C_{\text {int II }}$ と, 弚れに対する圧力抗力と摩擦抗力の 寄与の内訳を整理した . 図中では斜線部が摩擦抗力で, 残 りが圧力抗力である . 


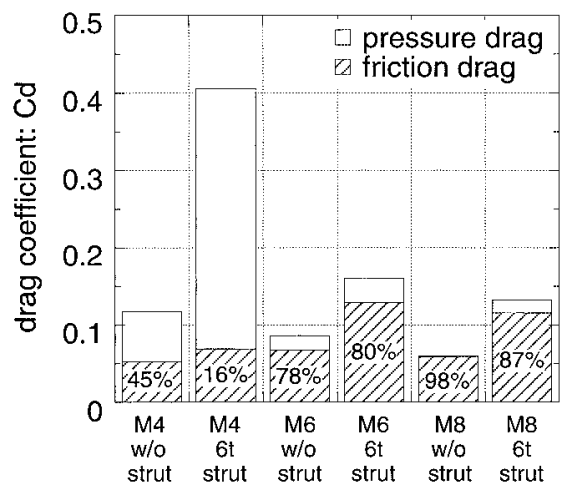

第10図 M4,6,8 各飛行条件における圧力抗力と摩擦抗力の内訳

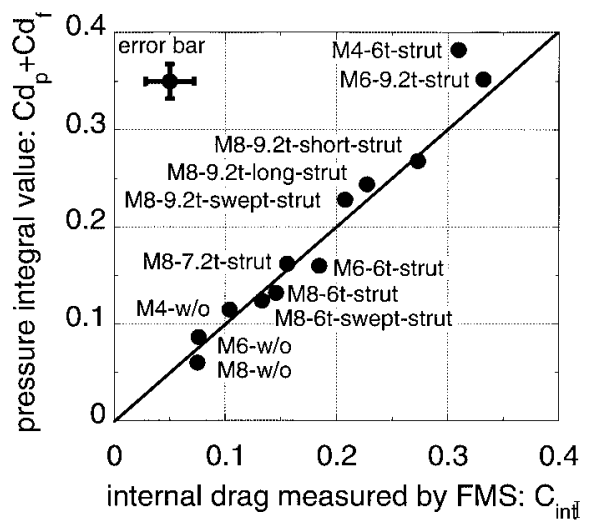

第11図 M4,6,8 各飛行条件における圧力抗力と摩擦抗力の内訳

第 10 図より，M4 ストラットなしでは，内部抗力に占め る摩擦抗力の割合いが $45 \%$ であったのに対し，M8 ストラッ 卜なしでは, 弚れが $98 \%$ まて増えた. 従って, M 数が高く なるほど摩擦抗力の割合いが増えることが分かる．これは 低 M 数ほど , 圧力抗力が大きくなるからである . ストラッ 卜を取り付けると，この傾向が一層強くなる. M 4 の $6 \mathrm{~mm}$ 厚ストラット付きでは, 内部抗力のうち $84 \%$, 大部分が 圧力抗力であった 。

3.3 抗力測定と壁圧測定における内部抗力の比較 第 11 図に抗力測定值から求めた内部抗力 $C_{\mathrm{int}} \mathrm{I}$ と，壁圧測定 值から算出した内部抗力 $C_{\text {int II }}$ を比較した . 図より○が 45 度線上にのっており，独立に求めた 2 つの内部抗力係数の 一致度は良い . M 8 ストラットなしでは $C_{\mathrm{int} \text { II }}$ が $C_{\mathrm{int}}$ より も $20 \%$ 小さくなった . これは, ストラットなしの抗力が小 さく, 天板形態抗力との差し引きで, 精度よく抗力を見積 るのか灘しいためである. 誤差解析 $\left.{ }^{6}\right)$ によれば, 総圧評価の 誤差が摩擦抗力の見積りにおよぼす影響は小さい，従って， 両者のずれの原因は, 圧力抗力, 特にストラット面での抗 力見積りにある . ストラットを取り付けた場合，両者のず れは M4-6 mm 厚ストラット付きでの $19 \%$ が最大であった .

このように，壁圧測定値を用いる第二の方法では，内部 抗力見積りへの総圧回復率の影響が小さく，内部抗力の見 積り精度は良い，従ってこの方法を用いて，圧力抗力と摩 擦抗力の発生分布を求め, 弚れに基づいてエンジン内部流 路形状の最適化が可能となる.
RJTF の M8 燃焼試験では，収縮比 8.3 で $460 \mathrm{~N}$ (推力 係数で 0.18$)$ の推力増分が観測されている5). 従って M8 条 件で正味推力を発生するためには，燃焼時の推力増分を大 きくすると同時に，エンジン内部抗力を $6 \mathrm{~mm}$ 厚ストラッ 卜装着時以下にしなければならない . 例えばストラットの 下流部を流線形化すれば，光の圧力抗力は M 8 時で $40 \%$ 低 下する . またインレット圧縮面のコンタ化やランプ圧縮 ，下 流側流路における抗力最少化 (base 抗力あるいは boat tail 抗力の減少) 等を検討しなければならない，なお第 10 図で 示すように，高マッ八数域ではエンジン抗力の $1 / 2$ 以上は 摩擦によるものである. 従って关の抗力と燃焼性能の最適 化は，エンジン内部需れ面積も含め行わなければならない .

$$
\text { 4. ま と め }
$$

ラムジェットエンジン試験設備の $1 / 5$ 縮尺の小型風洞を 用いて, 各種形態のストラットを装着したスクラムジェット エンジン模型を用い，M4，M6，M8 の各飛行条件で，壁 圧分布と抗力を同時測定した. 乥して 2 つの方法で, エン ジン全体の総圧回復率とエンジン内部抗力を見積り，両者 を比較し光の一致度を調べ，以下の結論を得た．

1) 抗力測定により，内部抗力を見積った . インレットの収 縮比の増加に伴い, M8 飛行条件のエンジン内部抗力は， ストラットなし形状での 0.075 から収縮比 8.33 のスト ラットを装着した模型の 0.273 に変化した。

2) 同じ M8 飛行条件の収縮比 8.33 の模型でも，ストラッ 卜形状により抗力は $24 \%$ 低下した .このように，スト ラット形状を最適化することで，内部抗力を小さくする ことができる .

3 ) 壁圧測定により, 圧力抗力と摩擦抗力の発生分布を明ら かにした．この手法により，抗力の観点からエンジン内 部流路形状の最適化が可能になる .

4) 抗力測定による内部抗力と壁圧測定による内部抗力は一 致した . 従って, 壁圧測定による内部抗力の見積り精度 は良く，この方法を用いて，摩擦抗力の見積りが可能で ある

\section{記号表}

$\mathrm{A}_{1} \quad$ ： 流路投影面積 $(=H \times W)$

$C_{0} \quad$ : 天板抗力係数

$C_{\text {add }}$ : 付加抗力係数

$C d_{\mathrm{f}}$ : 摩擦抗力係数

$C d_{\mathrm{p}}$ : 圧力抗力係数

$C_{\text {duct }}$ ：ダクト抗力係数 $\left(=C_{\text {int }}-C_{\text {add }}\right)$

$C_{\mathrm{FMS}}$ ：FMS 測定値

$C_{\text {ext }}$ : 外部抗力係数

$C_{\text {int I }}$ ： 内部抗力係数 (抗力測定) $\left(=C_{\text {tot }}-C_{\text {ext }}\right)$

$C_{\text {int II }}$ ： 内部抗力係数 (壁圧測定) $\left(=C d_{\mathrm{p}}+C d_{\mathrm{f}}\right)$

$C_{\text {tot }}:$ 全抗力係数 $\left(=C_{\mathrm{FMS}}-C_{0}\right)$

$c_{\mathrm{f}} \quad$ : 壁面摩擦係数

$M \quad$ ：マッハ数

$P_{\mathrm{w}} \quad$ : 壁圧 


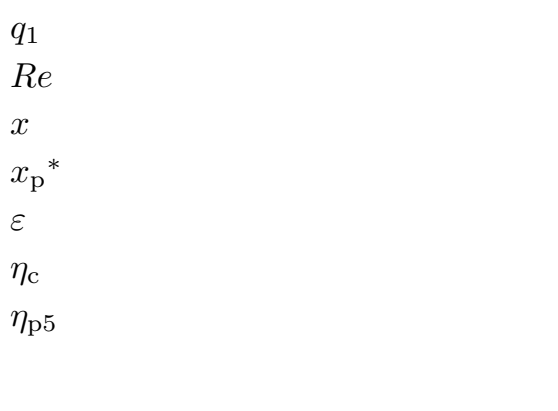

1) Voland, R. T.: Methods for Determining the Internal Thrust of Scramjet Engine Modules from Experimental Data, AIAA Paper 90-2340, 1990.

2) Mitani, T., Kanda, T., Hiraiwa, T., Igarashi, Y. and Nakahashi, K.: Drags in Scramjet Engine Testing: Experimental and Computational Fluid Dynamics Studies, J. Propul.
Power, 15 (1999), pp. 578-583.

3) 三谷 徹, 平岩徹夫, 苅田丈士 , 志村 隆, 富岡定毅, 小林 完, 泉川宗男，櫻中 登，渡辺修一：小型風洞とエンジン補完実験， NAL TR-1458, 2002.

4) 三谷 徹, 樽川雄一, 泉川宗男, 渡邊修一, 志村 隆 : スクラム ジェットエンジンの 3 分力測定 2) 外部流と境界層吸い込みの影 響，日本航空宇宙学会論文集，51 (2003), pp. 252-259.

5) Kobayashi, K., Tomioka, S., Kanda, T., Tani, T., Hiraiwa, T. and Saito, T.: Modified Water-Cooled Scramjet Engine Tested under M8 Condition, AIAA Paper 2001-3202, 2001.

6) Mitani, T., Hiraiwa, T., Tarukawa, Y. and Masuya, G. Drag and Total Pressure Distributions in Scramjet Engines at Mach 8 Flight, J. Propul. Power, 18 (2002), pp. 953-960. 7）樽川雄一：東北大学修士論文，2002.

8) Rubesin, M. W., Mayden, R. C. and Varga, A. A.: An Analytical and Experimental Investigation of the Skin Friction of the Turbulent Boundary Layer on a Flat Plate at Supersonic Speeds, NACA TN 2305, 1951. 